\title{
The Effect of a Single Cigarette Puff on Air Flow in the Lungs.
}

\author{
VI Iyawe ${ }^{1}$, CN Ejindu ${ }^{1}$, MI Ebomoyi ${ }^{1}$ and HA Oboh ${ }^{2}$
}

\begin{abstract}
Peak expiratory flow rate (PEFR) was measured in 160 apparently healthy males, 1550 years of age, consisting of 60 non-smokers (control) and 100 who volunteered to smoke (experimental subjects). Out of the 100 subjects, 50 who were also non-smokers smoked a cigarette through a single suck (puff). Another 50 who previously smoked also took a single puff. Results indicate that PEFR for the control group was $558 \pm 10 \mathrm{~L} / \mathrm{min}$ in the 30 younger subjects (15-30yrs) and $516 \pm 11 \mathrm{~L} / \mathrm{min}$ in the 30 older subjects (31 50 years) and the difference was significant $(\mathrm{P}<0.05)$ The initial PEFR for smokers before they took a puff was significantly lower than for non-smokers $(\mathrm{P}<0.05)$. After a puff, there was no significant difference in PEFR between the smokers and non-smokers in the younger group. In the older group, PEFR of smokers was lower than those of non-smokers $(\mathrm{P}<0.05)$. Overall, a puff of cigarette significantly reduced PEFR in non-smokers, but the reduction in PEFR following a single puff in smokers was not significant.
\end{abstract}

\section{INTRODUCTION}

Cigarette is produced from tobacco. The tobacco plant is believed to have originated in the western Hemisphere. ${ }^{1}$ The plant is grown for its leaves, which can be smoked, chewed or sniffed for a variety of effects. It is considered an addictive substance especially because of its nicotine content.

KEYWORDS: PEFR, Cigarette puff.

Departments of ${ }^{1}$ Physiology and ${ }^{2}$ Medical Biochemistry, School of Basic Medical Sciences, College of Medical Sciences, University of Benin, Benin City, Nigeria.

Correspondence: Professor V.I. Iyawe, Department of Physiology, School of Basic Medical Sciences, College of Medical Sciences, University of Benin, Benin City, Nigeria. Tel: 08029501895.
When a cigarette is lit, it emits smoke which contains nicotine and over 19 known carcinogens (most, collectively known as "tars") and more than 4,000 chemicals. ${ }^{2}$ A puff of cigarette is estimated to contain $10^{16}$ oxidants. The degree of smoking or smoke exposure can be ascertained by measuring the serum levels of continine (a metabolite of nicotine) Despite knowing that inhaling cigarette can seriously damage the health of humans, its social importance has grown over the years, even to the point of denoting the "modern or liberated woman" in the western world during the twentieth century. ${ }^{1}$

Cigarette smoking is a major component of indoor and outdoor air pollution causing environmental tobacco 
smoke and secondary smoking in other people. It contributes to a remarkable number of diseases, including coronary heart disease, stroke, chronic obstructive airway disease, peptic ulcer, peripheral vascular disease and many types of cancers. ${ }^{3}$ Thus smoking affects several systems of the body, most especially the first line organ, the lungs. The harmful substances which enter the lungs, spread through the body and can reach the brain, heart and other organs within 10seconds of the first puff. ${ }^{2}$

Inhalation of cigarette puff has an immediate effect on respiration by increasing airway resistance and therefore reducing the amount of oxygen absorbed into the body. ${ }^{4}$ Smoking causes a chronic (or long term) swelling of mucous membranes, which also leads to increased airway resistance. It induces chronic irritation of the respiratory lining and wide variety of carcinogens in the cells lining the respiratory tract. These changes lead to cancer. ${ }^{5}$ Smoking greatly affects the lungs from an annoying repeated cough to grave illnesses like chronic bronchitis, emphysema and bronchial carcinoma. ${ }^{6}$ The risk to the respiratory system, especially the risk of cancer continues to plague the ex-smoker for years after quitting. There is increased incidence of asthma in children of smoking mothers. ${ }^{7}$ There is also retardation of the rate of lung development and lung function in these children and those involved in childhood and adolescent smoking. ${ }^{4}$

The above effects on the respiratory system are well known in chronic smokers. The acute effect of cigarette smoke is not well documented. The present study, therefore, examines the effect of cigarette smoke (a single suck or puff) on air flow in the lungs, by measuring PEFR soon after the puff. PEFR is generally considered as a sensitive indicator of changes in elastic recoil pressure and/or inflammatory change in the bronchiolar walls. ${ }^{8}$

\section{MATERIALS AND METHODS}

The work was carried out in Benin City using staff and students of the University of Benin. A total of 160 subjects, all males volunteered for the study. Females refused to participate in the study. This was not surprising since smoking by females is not an acceptable social habit in Nigeria. Also, it was difficult to get more male volunteers because of the scare of the 'diseases' associated with cigarette smoking, However, the volunteers were divided into groups according to their smoking habits and ages.

The 160 males consisted of 60 nonsmokers who served as control (Gp1 A and B), 50 non-smokers who took a puff (Gp2 C and D) and 50 smokers who took a puff, (Gp3 $\mathrm{E}$ and F). Each of the 3 groups was subdivided into two equal groups based on ages 15-30 years and 31-50 years (table 1 ).

Prior to any measurement, questionnaires eliciting information on age, medical history and smoking habit was administered. The height, weight and chest circumference were recorded. As in many health surveys, only one parameter was measured, the PEFR, that is, the fastest rate of exhalation which gives an indication of airway resistance. A Wright Peak Flow meter was used in the measurement. Volunteers gave informed consent for the study and Ethical Committee approval was obtained.

Subjects were made to practice and perfect the required breathing manoeuvre before recorded measurements of PEFR were taken. The test was carried out in all the subjects in the sitting position. The highest 
PEFR from three attempts was recorded and used for analysis. ${ }^{9}$

PEFR was measured in the subjects before and after a puff of cigarette except in the controls in whom PEFR was measured without inhalation of cigarette smoke. The subjects were trained in the act of 'puffing'. Each puff of cigarette lasted for approximately 2 seconds and measurements of PEFR started 10 to 15 seconds after the puff. For the smokers, a smoke free interval of 24 hours was observed before the puff and PEFR measurements. The data were subjected to statistical analysis and $\mathrm{P}$ values calculated using the students t-test.

\section{RESULTS}

The results are presented as mean and standard error of mean (tables 2 and $3 a$ and $b$ ). Overall, the age, height, weight, and chest circumference of non smokers and smokers were not significantly different (table 2). PEFR of the younger subjects was higher than those of older subjects. There was no significant difference between the PEFR of non-smokers and control in the two age groups (1 vs 2, table 3a). However, there was a significant reduction in the PEFR of nonsmokers of both groups after taking a puff ( $\mathrm{p}<$ 0.05) (table $3 b$ ) and figure 1 (Gps C and D).

For smokers, their initial PEFR were lower than those of the control (table 3a, 1 vs 3 and 2 vs 3). The lower values in comparison with control were more pronounced for smokers in the older age group $(\mathrm{P}<0.01)$. Furthermore, a comparison between smokers and non smokers shows that the PEFR of smokers was lower than those of non smokers $(\mathrm{P}<0.05)$ for both age groups (tables $3 \mathrm{a}$ and $3 \mathrm{~b})$. When the smokers took a puff, there was a reduction in their PEFR, like those of the non smokers, but the reduction was not significant (figure 1, Gps E and F).

\section{DISCUSSION}

The present study was designed to examine the effect of cigarette puff on lung function. It is unique in that it focuses on the acute

Table 1: Subject groups according to smoking habit and age

\begin{tabular}{|c|l|c|l|}
\hline Group & Category & No. of subjects & Age Range \\
\hline 1. A (Control) & Non-Smokers, no puff & 30 & 15 -30yrs \\
B. (Control) & Non-Smokers, no puff & 30 & $31-50 y r s$ \\
\hline 2. C & Non-Smokers, took puff & 25 & $15-30 y r s$ \\
D & Non-Smokers, took puff & 25 & $31-50 y r s$ \\
\hline F E & Smokers, took puff & 25 & $15-30 y r s$ \\
\hline
\end{tabular}


Table 2: Comparison of anthropometric parameters of non-smokers and smokers (Mean \pm s.e.m.)

\begin{tabular}{|c|c|c|c|c|c|c|c|}
\hline \multirow[t]{2}{*}{$\mathrm{S} / \mathrm{No}$} & \multirow[t]{2}{*}{ Parameter } & \multirow{2}{*}{$\begin{array}{l}\text { Gp } 1 \\
\text { Control }\end{array}$} & \multirow{2}{*}{$\begin{array}{l}\text { Gp2 } \\
\text { Non-smoker }\end{array}$} & \multirow{2}{*}{$\begin{array}{l}\text { Gp3 } \\
\text { Smokers }\end{array}$} & \multicolumn{3}{|c|}{ P-Value } \\
\hline & & & & & 1 vs 2 & 1 vs 3 & 2 vs 3 \\
\hline \multirow[t]{2}{*}{1} & Age (15-30) & $\begin{array}{l}22.3 \\
+6.46\end{array}$ & $\begin{array}{l}24.08 \\
+0.4\end{array}$ & $\begin{array}{l}23.84 \\
\pm 0.72\end{array}$ & $<0.05$ & $<0.05$ & N.S \\
\hline & 31-50 years & $\begin{array}{l}37.53 \\
+0.97\end{array}$ & $\begin{array}{l}38.56 \\
+1.16\end{array}$ & $\begin{array}{l}38.08 \\
\pm 1.2\end{array}$ & N.S & N.S & N.S \\
\hline \multirow[t]{2}{*}{2} & Height (15-30) & $\begin{array}{l}1.66 \\
+0.002\end{array}$ & $\begin{array}{l}1.73 \\
\pm 0.01\end{array}$ & $\begin{array}{l}1.69 \\
\pm 0.02\end{array}$ & $<0.05$ & N.S & $<0.05$ \\
\hline & $(31-50)$ & $\begin{array}{l}1.64 \\
\pm 0.01\end{array}$ & $\begin{array}{l}1.69 \\
+0.01\end{array}$ & $\begin{array}{l}1.68 \\
\pm 0.04\end{array}$ & $<0.05$ & N.S & N.S \\
\hline \multirow[t]{2}{*}{3} & Weight (15-30) & $\begin{array}{l}70.29 \\
+2.29\end{array}$ & $\begin{array}{l}67.45 \\
+1.46\end{array}$ & $\begin{array}{l}67.73 \\
\pm 1.57\end{array}$ & N.S & N.S & N.S \\
\hline & $(31-50)$ & $\begin{array}{l}74.99 \\
+1.78\end{array}$ & $\begin{array}{l}73.99 \\
+1.80\end{array}$ & $\begin{array}{l}72.08 \\
+1.09\end{array}$ & N.S & N.S & N.S \\
\hline \multirow[t]{2}{*}{4} & $\begin{array}{l}\text { Chest } \\
\text { Circumference } \\
(15-30 \text { years })\end{array}$ & $\begin{array}{l}83.83 \\
+3.14\end{array}$ & $\begin{array}{l}79.16 \\
\pm 1.57\end{array}$ & $\begin{array}{l}80.64 \\
+2.0\end{array}$ & N.S & N.S & N.S \\
\hline & (31-50 years) & $\begin{array}{l}87.64 \\
+3.07\end{array}$ & $\begin{array}{l}91.42 \\
+1.3\end{array}$ & $\begin{array}{l}85.58 \\
+1.18\end{array}$ & N.S & N.S & $<0.05$ \\
\hline
\end{tabular}


8 Journal of Medicine and Biomedical Research

Table 3a: Comparison of PEFR of the control, non-smokers and smokers before and after a puff of cigarette (Mean \pm s.e.m.)

\begin{tabular}{|c|c|c|c|c|c|c|}
\hline & Gp 1 & $\mathrm{Gp} 2$ & Gp3 & \multicolumn{3}{|c|}{ P-Value } \\
\hline & Control & Non-smoker & Smokers & 1 vs 2 & 1 vs 3 & 2 vs 3 \\
\hline $\begin{array}{l}\text { P.E.F.R before } \\
\text { smoking a puff } \\
\text { of cigarette } \\
(15-30 \text { years })\end{array}$ & $\begin{array}{l}553 \\
+11.87\end{array}$ & $\begin{array}{l}553 \\
+11.15\end{array}$ & $\begin{array}{l}530 \\
+8.22\end{array}$ & N.S & $<0.05$ & $<0.05$ \\
\hline (31-50 years) & $\begin{array}{l}516 \\
+11.87\end{array}$ & $\begin{array}{l}518 \\
+11.15\end{array}$ & $\begin{array}{l}456 \\
\pm 10.7\end{array}$ & N.S & $<0.001$ & $<0.001$ \\
\hline $\begin{array}{l}\text { P.E.F.R before } \\
\text { smoking a puff } \\
\text { of cigarette } \\
\text { (15-30 years) }\end{array}$ & & $\begin{array}{l}521 \\
+13.78\end{array}$ & $\begin{array}{l}513 \\
+9.50\end{array}$ & & & N.S \\
\hline (31-50 years) & & $\begin{array}{l}485 \\
+12.87\end{array}$ & $\begin{array}{l}442 \\
+10.5\end{array}$ & & & $<0.05$ \\
\hline
\end{tabular}

Table 3b: Comparison of P.E.F.R of the Non-smokers and smokers before and after a puff of cigarette (Mean \pm s.e.m.)

\begin{tabular}{|l|c|c|c|c|}
\hline S/No & NON-SMOKERS & $\begin{array}{c}\text { BEFORE A } \\
\text { PUFF }\end{array}$ & $\begin{array}{c}\text { AFTER A } \\
\text { PUFF }\end{array}$ & P-VALUE \\
\hline 1. & $(15-30$ years $)$ & $553 \pm 11.15$ & $521 \pm 13.78$ & $\mathrm{P}<0.05$ \\
\hline 2. & $(31-50$ years $)$ & $518 \pm 11.15$ & $485 \pm 12.86$ & $\mathrm{P}<0.05$ \\
\hline & $\underline{\text { SMOKERS }}$ & & & \\
\hline 1. & $(15-30$ years $)$ & $530 \pm 8.22$ & $513 \pm 9.50$ & $<0.05$ (N.S) \\
\hline 2. & $(31-50$ years) & $456 \pm 10.7$ & $442 \pm 10.5$ & $<0.05$ (N.S) \\
\hline
\end{tabular}


HISTOGRAM ON THE EFFECTS OF CIGARETTE PUFF

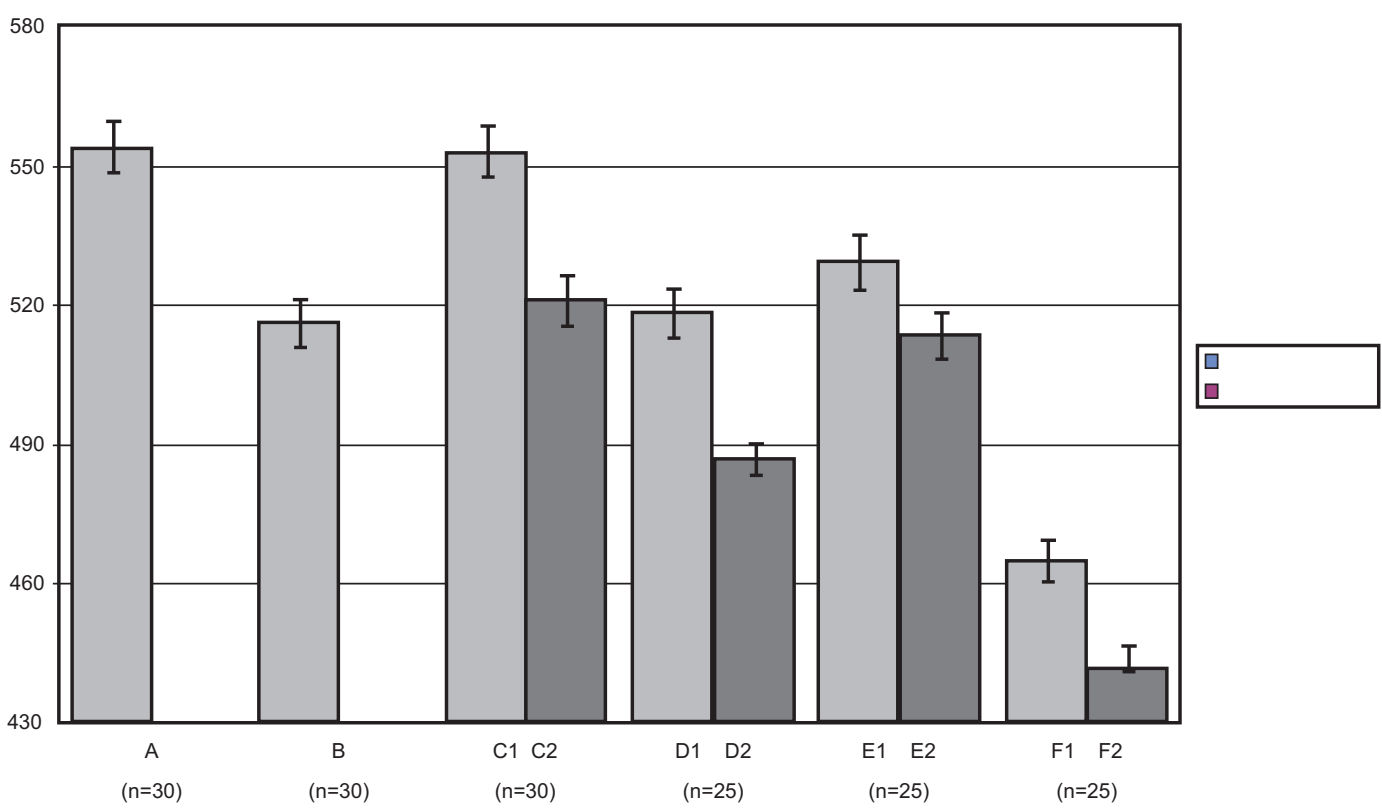

Figure 1

Figure 1 showing a reduction in PEFR in all groups after a puff

\section{KEYS}
○ A-Control (15-30Yrs)
O B-Control (31-50yrs)
O C-None-Smokers (15-30Yrs)
O D- None-Smokers (31-50yrs)
O E-Smokers (15-30yrs)
O F-Smokers (31-50)
O 1-Before a Puff
O 2-After a Puff 
response to a single puff of cigarette smoker. It has the advantage that the volunteers do not inhale a large quantity of smoke which can be deleterious to their health. The measured index, PEFR, is generally considered as a sensitive indicator for changes in elastic recoil pressure and/or the resistance to airflow in medium and small airways. ${ }^{10,11}$

It has been known that various indices of lung function including $\mathrm{FEV}_{\mathrm{I}}$ and PEFR decrease over time in smokers. ${ }^{12,13}$ Furthermore, inhalation of cigarette smoke has an immediate effect on respiration by increasing airway resistance. ${ }^{14}$ Exposure to environmental tobacco smoke (E.T.S.) or passive smoking leads to reduced lung function, ${ }^{6,15}$ increased risk of lower respiratory tract illness and acute exacerbation of asthma. ${ }^{16}$

The findings of this study for the normal control group are in conformity with those of previous studies on Nigeria. ${ }^{17,18,19}$ However, the PEFR of the three groups (control, non-smokers and smokers) were significantly higher in the younger age group than the older ones. This is attributable to the effect of age on lung tissues. With age, the expiratory muscles used for it hard to exclude latent diseases in the older age group..$^{20}$ Also, the PEFR is subject to wide variabilities. These include height, weight, and chest circumference. In this study, these variables did not make significant contribution to the effect of the puff. Height and chest circumference might have affected the PEFR, but the marked changes in PEFR cannot be attributed to these variables.

The study reveals a significant reduction in the PEFR of non-smokers after taking a puff of cigarette. On the other hand, the decrease in PEFR of smokers after a puff was not significant. Smokers have a lower level of lung function than those who have not smoked. ${ }^{21}$ The smokers had a low basal PEFR. Hence no significant reduction after a puff.

How does cigarette smoke increase airway resistance and decrease PEFR? Several mechanisms exist. First, it can be attributed to rapidly responding receptors with in the a i r w y c a u sing bronchoconstriction and tachypnoea. Secondly, the accumulated effect of tobacco smoke is an increased load of oxidants in the respiratory tract, both directly by inhalation of oxidants in the smoke and indirectly by activation of inflammatory cells. ${ }^{22}$ Thirdly, smoking significantly increased progressive deterioration of the lung functions and is a risk factor in chronic obstructive pulmonary diseases, in which pulmonary mechanics deteriorates and causes loss of elastic recoil of the lungs and slowing forced expiration. ${ }^{4}$ Fourthly, with nicotine, mucus-producing cells grow in size and number, so that the amount of mucus secreted is more and also thicker. ${ }^{4}$ Fifthly, cigarette smoke slows the movement of cilia on the airway epithelium and also reduces their number, making mucociliary clearance difficult and further clogging up the airway. ${ }^{23}$

Furthermore, nicotine promotes tumor growth and angiogenesis in adults. It can induce angiogenesis by activating nicotinic acetylcholine receptors (nAchRs) on the surface of endothelial cells which stimulates their proliferation and the subsequent formation of blood vessels. ${ }^{24}$ Cigarette smoke also increases levels of chemo attractant protein and vascular endothelial growth factor which also aid angiogenesis and tumour growth. ${ }^{25}$ It is now known that cigarette smoke can induce remodelling in the trachea in the absence of inflammation. 
Some form of airway remodeling might have been established in the older smokers. ${ }^{26}$

\section{CONCLUSION}

In conclusion, PEFR was reduced after a puff of cigarette. Smoking status influenced the PEFR value as smokers had substantially lower values at the outset of the study. It is well known that from a puff of cigarette, smokers move to a stick and then from sticks to addiction and so the effects accumulate. The effect of tobacco smoking can be deleterious. If a single puff increases airway resistance and reduces PEFR, chronic smoking is bound to do much damage to the lungs.

\section{References}

1. Bartel M. Health effect of Tobacco use and exposure. Monaldi Arch Chest Dis 2001; 56: 545-550.

2. Winstanley M, Woodward S and Walker N. Tobacco in Australia, Facts and Issues. Austrl Ann Med 1995; 16: 31-40.

3. Jaakkola M, Jaakkolan P, Ernst P, Becklate M. Ventilatory Lung function in young cigarette smokers: a study of susceptibility. Eur Respir J 1991; 4: 643-650.

4. Gold D. Wang XB, Wypij D, Speizer FE, Ware JH and Docey DW. Effects of cirgarette smoking on lung function of adolescent boys and girls. N Engl J Med 1996;335:931 937.

5. Liston J. Breast feeding and the use of recreational drugs - alcohol, caffeine, nicotine and marijuana. Breast-feed Rev 1998 (Aug 6); 2: 27-30.
6. Pershagen G. Accumulating evidence on health hazards of passive smoking (Review). Act Paediatr,1999 (May); 88(5): 490-520.

7. Martinez FD, Cline $\mathrm{M}$ and Burrow B. Increased incidence of asthma in children of smoking mothers. Pediatrics 1992; 89: 21-26.

8. Polatly M, Erdinc M, Erdinc E. The early effect of smoking on spirometing and transfer factor. Turk Resp J 2000; 1(2): 31-34.

9. Iyawe VI, Igweh JC, Orie NN and Umapathy E. Time Course and Bronchodilator effect of caffeine in young Nigerians. J Physiol Sci 1990; 6: $50-56$

10. Josh LN, Hoshia VD. Effect of forced breathing on ventilatory function of the Lungs. J Postgrad Med 1998; 44(3): 67-69.

11. Reddy TS, Guleria S, Sanjeer S, Sharina SK and Pandy JK. Domestic cooking fuel and lung functions in healthy non smoking women. Indian J Chest Dis Allied Sci 2004; 46: 85-89.

12. Kuperman AS and River JB. The variable effect of smoking on pulmonary function. Chest 1973; 63: 655-660.

13. Bosse R, Spabow D, Gawey AJ, Costa PT, Weiss ST and Rowe JW. Cigarette smoking, aging and decline in pulmonary fuction - A Longitudinal study. Arch Environm Hlth 1980; 35(4): 247252.

14. Chan-yeung $\mathrm{M}$ and DimichWard $\mathrm{H}$. Respiratory Health effects of exposure to environmental tobacco smoke. Respirology 2003; 8(2): 131139. 
15. Hecht SS. Tobacco Carcinogens, their biomarkers and tobacco-induced cancer. Nature Rev Cancer 2003; 4: 733744 .

16. Mannino DM, Homa DM and Road SC. Involuntary Smoking and Asthma severity in children. Chest 2002; 122(2): 409415.

17. Femi-Pearse D and Elebute EA. Ventilatory function in healthy adult Nigerians. Clin. Sci 1971; 41: 203-211.

18. Ali MA. Racial differences in ventilatory functions. Nig J Physiol Sci 1990; 6: 59-62.

19. Ebomoyi MI and Iyawe VI. Variations of peak flow rate with anthropometric determinants in a population of healthy adult Nigerians. Nig J Physiol Sci 2005; 20: 85-89.

20. Alakija W, Iyawe VI, Jarrikre LN and Chiwuzie JC. Ventilatory function of workers at Okpella Cement Factory in Nigeria. WAfr JMed 1990; 9(3): 187192.
21. Lew EA, Garfinkel L. Differences in mortality and longevity by sex, smoking habits and health status. Society of actuaries Transaction 1987; 18: 24-28.

22. Kucoks, Cokdenizr, Atmaca, Uyram I, Buhur A and Taskih O. The effect of smoking on the glutathione levels in bronchoalveolar lavage fluid. Tr $J$ of Med. Sc. Tubitak1999; 20:643-647.

23. West JB. Respiratory Physiol The Essentials. $5^{\text {th }}$ Ed. (Williams and Wilkins, Baltimore) 1995; P.10.

24. Zhu B, Enstrom JE and Kabat GC. Second hand smoke stimulates tumor angiogenesis and growth.. Cancer cells 2003; 4: 191196.

25. Flintoft L. Carcinogenesis: Inhaling can seriously damage your health. Nature 2003; 3: 800.

26. Iyawe VI and Ebomoyi MI. Current developments in the physiology and management of asthma. Nig J Physiol Sci 2005; 20:1929. 